\title{
集水井集水工法によるすべり面付近の間隙水圧の変動特性 一埼玉県児玉郡児玉町平沢地すべり地を例として一
}

\author{
The Characteristics of Pore Water Pressure Fluctuation on the Slip Surface Based on \\ Drainage Well Works : Study of Tairasawa Landslide Area,Saitama Prefecture.
}

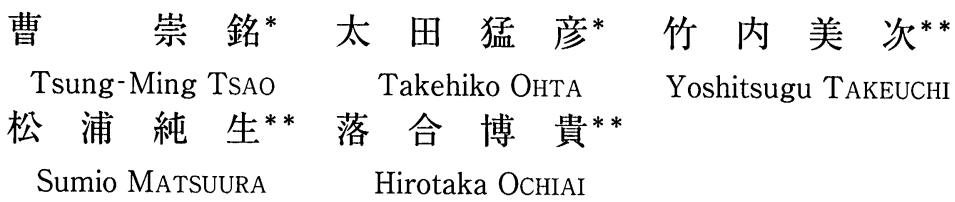

\begin{abstract}
Pore water pressure fluctuation is proved to be an important cause of landslide movement in landslide areas, but it is difficult to observe the mechanism of pore water pressure fluctuation at the various depth of slip surface. The purpose of this paper is to examine the pore water pressure fluctuation in shallow and deep stratum at the slip surface. The data used in this study was collected at Tairasawa landslide area during $1983 \sim 1985$. Two observational methods are considered. (1) The pressure heads were measured in the vertical observation borehole with a screened section. at the designated depth of slip surface. (2) The horizontal borehole of drainage wells were drilled for confined groundwater in a screened section at the same depth of slip surface. The rainfall, pressure head and drainage discharge were observed before and after the drainage well works.

The results indicated that after drilling a horizontal borehole,the pore water pressure was low in shallow and deep stratum at the slip surface. It is possible to judge the effects of drainage well works by comparing the drop of pore water pressure before and after the works. Furthermore,the drop of pore water pressure at the slip surface have two significant characteristics. First,the dropping variation of pore water pressure is corresponding to drilling depth and seepage water in a horizontal borehole. Secondly, the dropping effects of pore water pressure can be clearly prove when the drilling direction of a horizontal borehole near the vertical observation borehole.
\end{abstract}

キーワード：集水井, 間隙水圧, 集水ボーリング, すべり面

\section{1.はじめに}

地すべりの発生原因は，降雨，融雪などによる間隙水 圧の上昇がすべり面付近のせん断の抵抗力を著しく減じ, 地すべり土塊の安定に直接影響を与え，地すべり運動が 活発化する。地すべりの誘因となる間隙水圧を排除する ため，地すべり抑制工として集水井の地下水排除工が広 く施工されている。現在, 集水井による地下水排除工は, 集水井の井筒と全孔ストレーナーの集水ボーリングを併 用し地下水を排除する排水工法である。

従来, 集水井による地下水排除工の効果を評価するた めには集水井付近に設置した全孔ストレーナー観測孔の

* 來京大学大学院毞学生命科学研究科

$* *$ 莍林水産省林野庁森林総合研究所
地下水位変化を利用し行われている。その効果は井戸理 論公式を安定計算に導入することにより検討されてきて いる。また図ー1の断面図に示すように地下水位の低下 量 $\Delta h$ の関係と集水ボーリングの施工密度についても多 くの研究1.22が行われている。

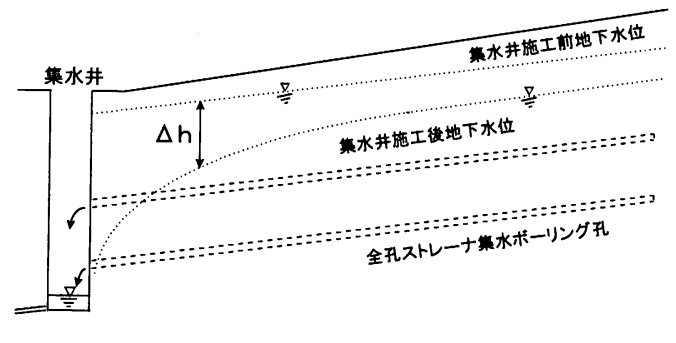

図-1 地下水位の低下効果 
一般に地すべり地の地下水挙動は，水文地質構造の複 雑さが原因となり，個々の調査地点や深度において異 なった挙動を示すことが多い。従来，地下水位の観測に は，ボーリング孔に多孔管を立て込んだ観測井の地下水 位変化を測定する方法が用いられてきた。しかしこの方 法では全孔ストレーナー観測孔の地下水位は複数の滞水 層の圧力水頭が混在した結果を計ることになり，実際に すべり面に作用する間隙水圧を見逃すことになってしま うという指摘 ${ }^{3 \sim 5}$ がされてきた。このため, 現在ではボー リング孔のすべり面付近に部分ストレーナー加工された 多孔管を入れ，ストレーナー区間に間隙水圧計を設置し て圧力水頭の計測をする例が多くなってきた ${ }^{6.7) 。 ~}$

一方，集水井を掘削し井内から集水ボーリングを打設 し地下水を排除することは，一般的に行われている。通 常の集水ボーリングでは，ボーリング孔全長にわたって ストレーナー加工を行う場合が大半である。しかし，集 水ボーリングの効果を評価・検討するためには, すべり 面付近に部分ストレーナー加工された集水ボーリングに よって地下水排除を行い，これと合わせて間隙水圧の変 化も測定することが望ましい。これにより他の地下水流 動層からの地下水がすべり面に作用する地下水に及ぼす 影響が緩和され，施工前後の間隙水圧の挙動はより精密 に計測できると考えられる。

そこで今回の研究では, 埼玉県児玉町平沢地すべり地 （平沢区）を対象とし，すべり面付近の間隙水圧の変動 特性を把握するためすべり面付近に部分ストレーナー区 間を設け，層別水位計を用いた圧力水頭（間隙水圧）を 測定した。また，それに対応する深度に集水井から部分 ストレーナーによる集水ボーリングを施工し，集水ボー リング施工前後の圧力水頭の変動を観測した。これらの 結果を基に，集水ボーリングの施工が圧力水頭の変動に 与える影響を明らかにし，さらに圧力水頭の時系列変動 と集水ボーリング孔の掘削延長・方向との関係を検討し て集水井の施工効果の評価を試みた。

\section{2. 平沢地すべりの概要及び観測方法}

今回の観測対象とした平沢地すべり地は，図ー 2 に示 すように埼玉県児玉町内小山川支流の平沢川右岸に発生

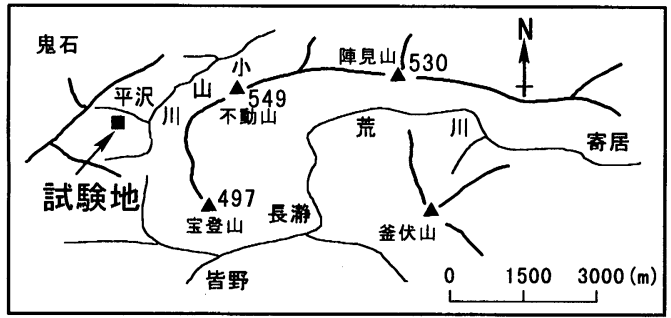

図一2 試験地の位置図
した面積 30 ha の地すべり地である。図ー3，4 に示す ように山頂直下は $40 \sim 60^{\circ}$ の急斜面で，その下部が 10 〜 $20^{\circ}$ の台地状地形となっている。山腹斜面は急〜緩〜 急と続き, 緩斜面は田畑として利用され, 湿地带や湧水 地がみられる。緩斜面と急斜面の境界付近（中部ブロッ クの滑落崖付近）に1〜2mの段差が連続している。地 質は長瀞系三波川変成岩地帯に属し, 黒色片岩と緑色片 岩の互層をなしており，軟弱で固結度が低い。この地す べり地では，集水井の施工効果を判定することを目的と した調查が 1981 年から 1990 にかけて森林総合研究所に よって行われた。本研究は地すべり地における(1)降雨量,

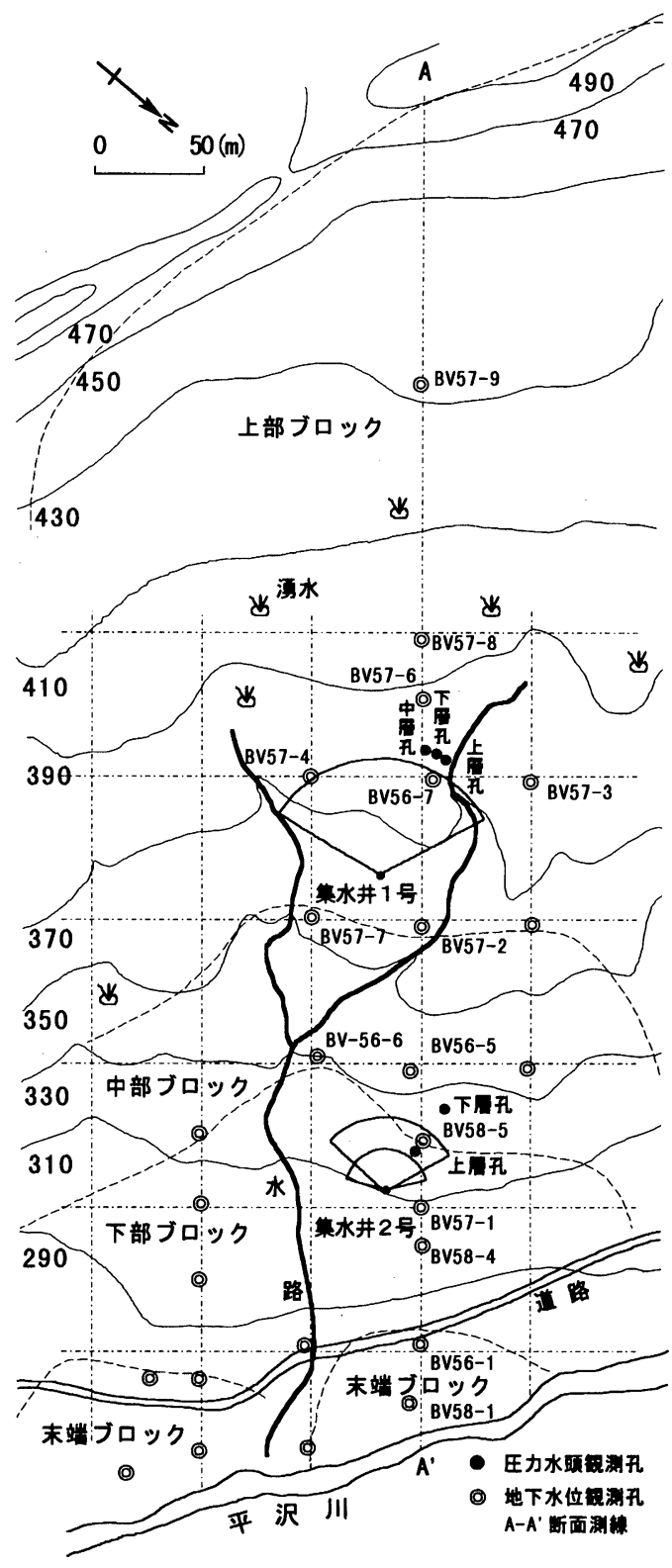

図一3 平沢地すべり地形及び集水井配置図 
(2)王力水頭，(3)集水ボーリング孔の掘削工程表，(4)バル ブの操作実験などのデー夕を基に，その相互関係につい て考察を行った。

\section{1 移動層及び地下水流動層の調査}

地すべり現㠩としては, 川腹斜面に発生しているき裂, 地表の凹凹, 民家の倾き, 町道の陥没, 平沢河岸の崩壊 性の地すべりがみられる。図ー4に示すようにボーリン グコア判定, 弾性波探查等の結果から地すべり土塊の浅 仢地すべり（深度 10〜15 m) は(1)を移動土塊として黒 色片岩, 緑色片岩の風化土で粘土化が進んでおり, 深痛 地すべり（深度 20２5 m) は(2)を移動土塊として黒色 片岩, 緑色片岩が破砕され, 軟質化し, 岩相のみられる 部分と磻混じり粘土状となっている部分が互㕌を成して いる。曲基岩層では黑色片岩, 緑色片岩が見られ, 上部 凧に比べると硬啠の棒状コアの岩相が多く介在している。 また滑落崖等がみられる地形的な特徵やパイプ雪計, 地 盤傾斜㖕等による土塊移動状況から地すべり地は上. 中・下（本端部）ブロックに区分される。上部ブロック は旧地すべり地で杉林であり，中・下部ブロックは主と して広葉樹で地すべり性の変動が認められる。

地下水は地下水検虽, 简易揚水試験の結果によると地 下水流動啱が調查ボーリング全孔（25孔）で認められ る。特に表-1に示す上部ブロックの BV 57-2，3，4，
8 の各孔は地下水が豊富に賦存していることが確認さ れる。更に現地調查から上部ブロックには湿地带, 涌水 点（18 䇢所）がある。上部ブロックは地下水涵養带で あり，しかも地下水の経路となって地下水が集まり易い 水文地質構造からなっているものと考えられる。した がって，上部ブロックからの地下水は中部〜下部ブロッ クの地すべり地に供給され, 地すべり活動を助長してい るものと推定される。

\section{2 部分ストレーナーの集水ボーリング}

中部〜下部ブロックへの地下水の供給を遮断する目的 で 1983 年には上部ブロックに集水井 1 号（深さ $25 \mathrm{~m}$ ) を施工し，1984 年は下部ブロックに集水井 2 号（深さ $15 \mathrm{~m}$ ）を施工した。集水井の井简は周辺の地下水の侵 入及び集水井内部の水の周辺への漏水を防ぐため, ライ ナープレート製井筒を組み立てながら余掘り空間にモル

表一1 地下水流動屏の優勢なボーリング孔

\begin{tabular}{|c|c|c|}
\hline ボーリング孔 & 解析区間 (m) & 流入量 (cc/min) \\
\hline BV57-2 & G.L 9. 25 16.25 & 6559 \\
& $22.00 \sim 22.5$ & 326 \\
\hline BV57-3 & $29.00 \sim 30.25$ & 594 \\
\hline BV57-4 & $17.25 \sim 27.00$ & 5805 \\
& $31.75 \sim 32.5$ & 317 \\
& $38.75 \sim 39.5$ & 401 \\
\hline BV57-8 & $14.25 \sim 25.00$ & 3327 \\
\hline
\end{tabular}
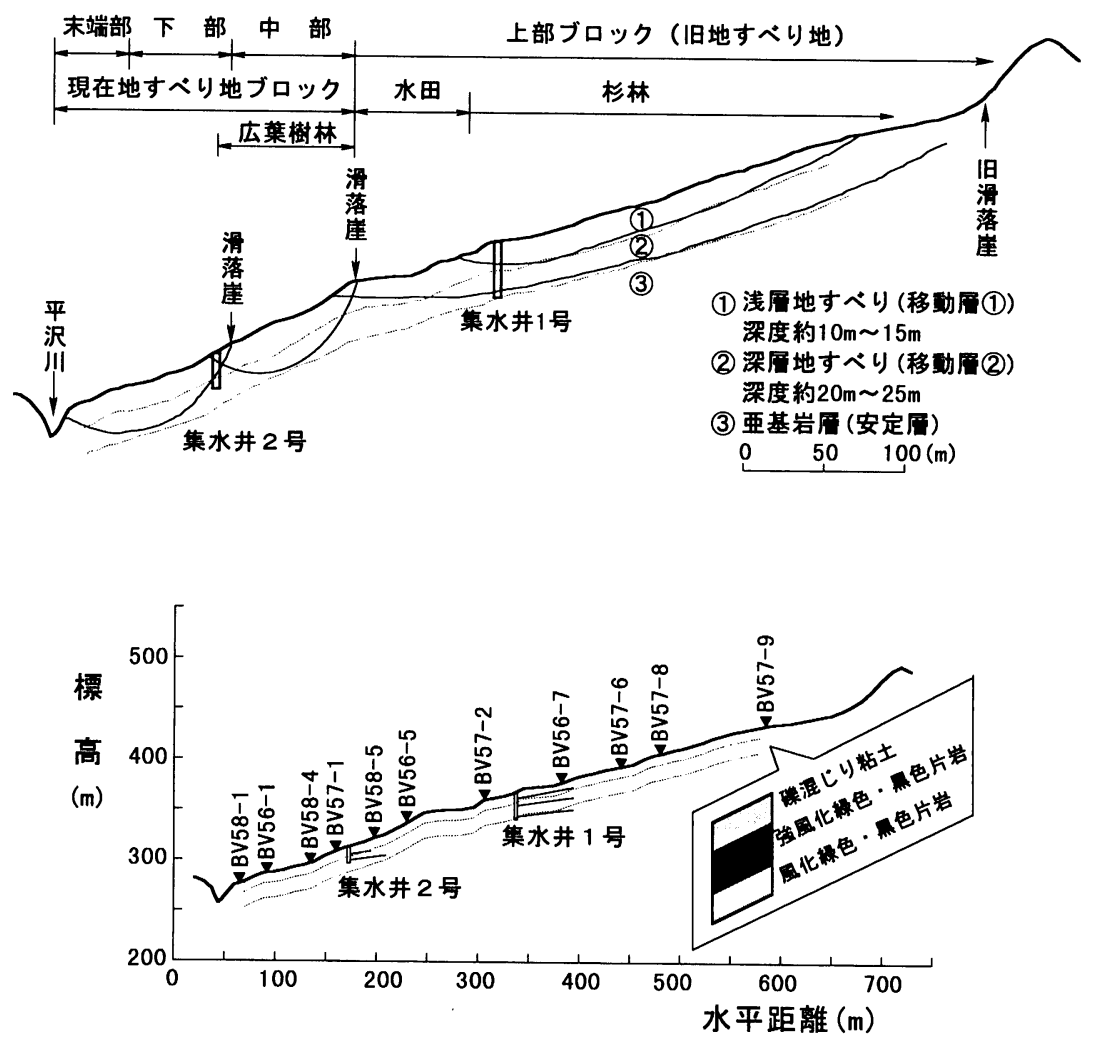

図一4試験地の $\mathrm{A}-\mathrm{A}^{\prime}$ 断面図及び地すべり移動層 
タルを注入している。各集水井の集水ボーリング孔は 1984 年に完成した。図－5に示すように集水井 1 号の集 水ボーリングは調査ボーリング BV 56-7 孔で検出され た三層の地下水流動層を集水井の三段集水ボーリング （上・中・下段）に対応して流動層内の地下水を排除さ せることを目的とする。井筒から扇状に掘削された長さ $55 \mathrm{~m}$ の集水ボーリングは先端 $10 \mathrm{~m}$ のみに部分ストレー ナー区間を設け地下水排除（自由・被圧地下水）を行っ た。集水井 1 号の集水ボーリング孔配置は図ー6 に示す。

一方，図ー4に示すように地すべり地の活動ブロック は, 中部ブロックから下部ブロックの末端部にかけて認 められた。これらのブロックの動きに対応するため，下 部ブロックにある二つのすべり層の間に次の集水井 2 号
を設置した。図ー7に示すように集水井 2 号による集水 ボーリングは, 移動層のすべり面及び調查ボーリング BV 58-5 孔で検出された二層の地下水流動層に対応する

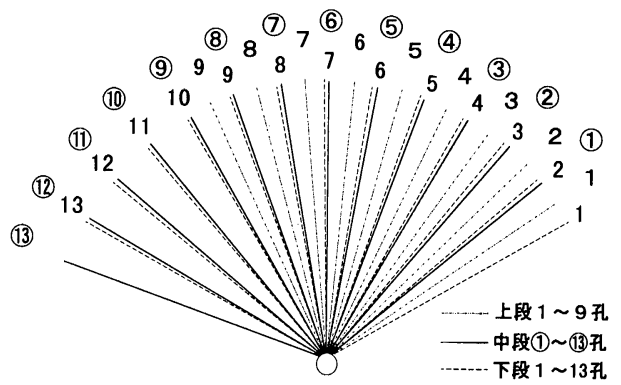

图一6 集水井 1 号の集水ボーリング孔配置

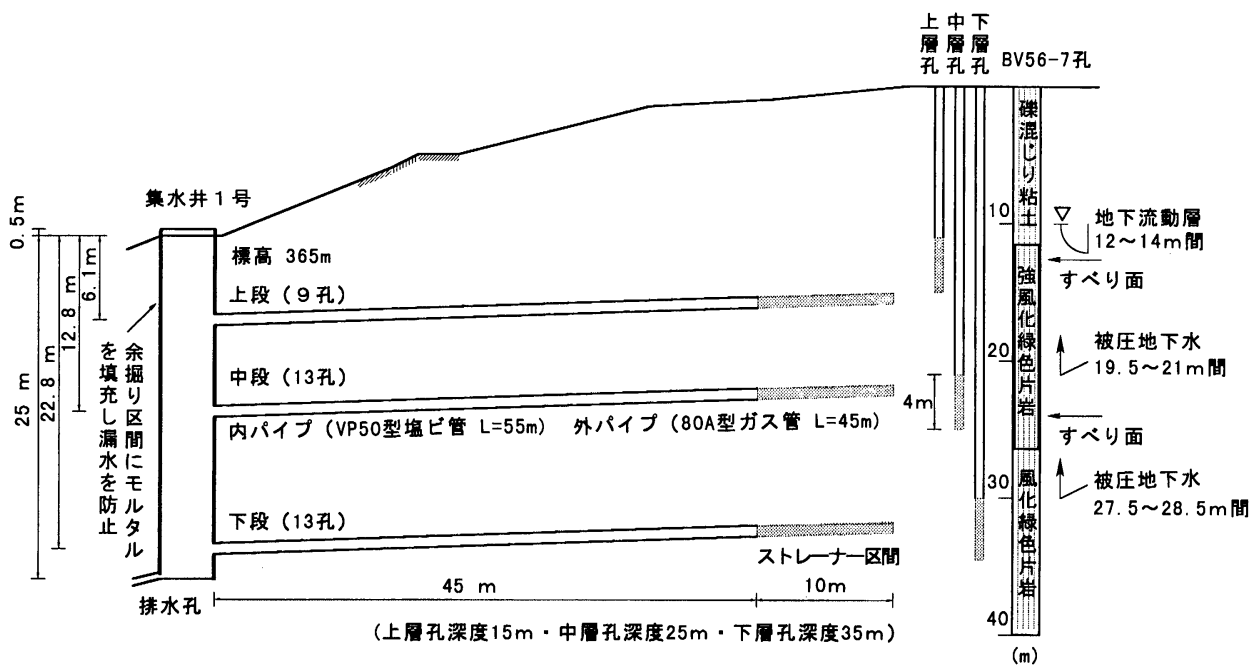

図-5＼cjkstart集水井 1 号の部分ストレーナー集水ボーリングの観測方法

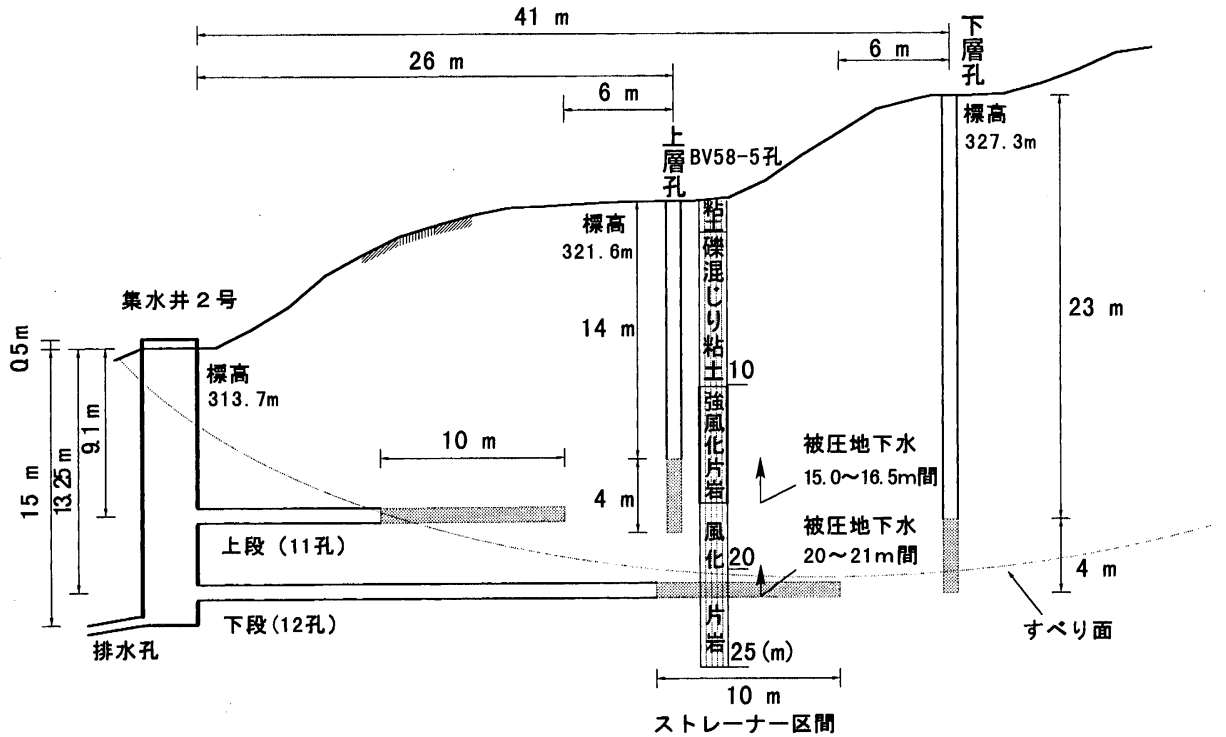

図-7 集水井 2 号の部分ストレーナー集水ボーリングの観測方法 
ために，二段（上段の長さ $20 \mathrm{~m}$ ，下段の長さ $35 \mathrm{~m}$ ）の 全長の買なる集水ボーリングによって行われている。集 水井 2 号の集水ボーリングは集水井 1 号と同様に掘削延 長の先端 $10 \mathrm{~m}$ のみに部分ストレーナー区間を設け地下 水排除を行った。集水井 2 号の集水ボーリング孔配置は 図ー8に示す。

集水井施工前後の水頭低下効果を評価するため, 各集 水井の集水ボーリングの先端付近にはまえもって圧力水 頭観測孔が設罚された。上部ブロックは集水井 1 号内の 上・中・下段の集水ボーリングを 3 層の圧力水頭観測孔 （上屏孔 $15 \mathrm{~m}$, 中屏孔 $25 \mathrm{~m}$, 下店孔 $35 \mathrm{~m}$ ) に対応して 設置した（図一5）。そして，圧力水頭観測孔の先端 $4 \mathrm{~m}$ のみに部分ストレーナー区閣を設け水位計を用いて圧力 水頭を観測している。また下部ブロックは集水井 2 号内 の上・下段に設圆した集水ボーリングを 2 層の庄力水頭 観測孔（上屏孔 $18 \mathrm{~m}$, 下層孔 $27 \mathrm{~m}$ ）に対応させて上記

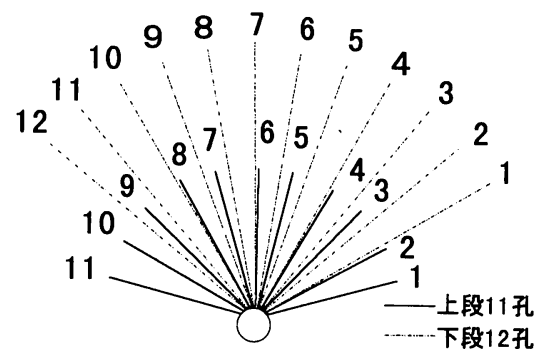

图ー8 集水井 2 号の集水ボーリング孔配置
と同様に $4 \mathrm{~m}$ の部分ストレーナー区間を設けて圧力水 頭を観測している。

図ー9は集水ボーリング孔及び圧力水頭観測孔のスト レーナー区間のパッカー处理とせん孔配置位置を模式的 に示したものである。パッカー処理の目的はストレー ナー区問に他の流動居からの地下水の流入をしゃ断する ため，ボーリング孔に挿入するパイプ (盐ビ管) のスト レーナー区間前に布パッカーを設置した。パッカーの施 工方法は長さ約 $50 \mathrm{~cm}$ の布パッカーをパイプの外壁周 りに固定させて注入するためのホースを・端に付設した。 パイプに处理した布パッカーをボーリング孔内に抻入し た後，布パッカーに付設した注入ホースから液体ミルク を布パッカーに加圧で注入する。そして，この布パッ カーを膨張させてパイプの外壁周りと孔壁間に密着させ てストレーナー区間のみに流入する地下水を保持する。

\section{3. 観測結果及び考察}

最近の地すべり学会誌において丸山ら（1996 年）は 以下の二点を指摘している。すなわち, 地下水排除工の 効果を定量的に評価するためには(1)現在行われている地 下水位の観測を間隙水圧の観測に切り替えること，(2)地 下水排除工の施工前から十分な地下水位・間隙水压の観 測を行い，施工後のデー夕と比較することが必要である としている。

本研究の試験地はまさに丸山らの指摘した問题点を克 服した試験地といえる。すなわち，平沢地すべり地にお

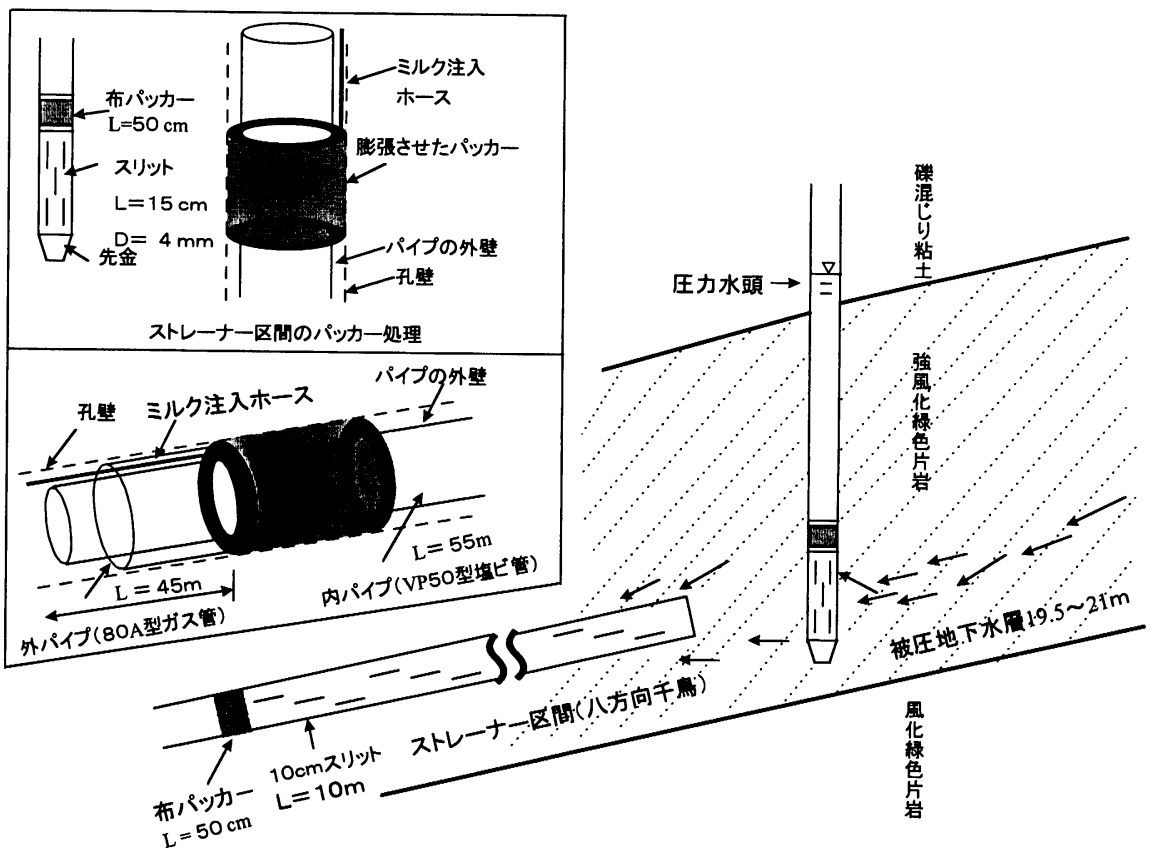

図ー9 ストレーナー区間のパッカー処理とせん孔配置位置図 
ける間隙水圧の観測は, 集水井の掘削前の 1983 年から 行われており，1984 年に集水井が施工された。観測期 間は(1)施工前の調査（1983 年）及び(2)集水井施工後の 調查（1984 年から 1985 年まで）の二期に分けて間隙水 压のデータを比較することにより，集水井掘削そのもの の効果を明らかにする。

(1)施工前の調查（1983 年）：地すべり対策工事は, 一 般に緊急を要するため, 施工効果判定に必要な施工前調 查は，必ずしも十分な期間にわたって実施されるとは限 らない。特に降雨条件は, 季節的な変動を伴うため, 長 期間の観測が必要である。そのため, あらかじめ一年以 上の降雨量や圧力水頭などのデー夕を収集した（集水井 1 号に対応する観測データは，1983 年 1 月から 1984 年 1 月まで, 集水井 2 号に対応する観測データは, 1983 年 10 月から 1984 年 11 月まで行った)。

(2)集水井施工後の調査（1984 年から 1985 年まで）: この調查は, 集水井の集水ボーリング孔の掘削によるす べり面に作用する圧力水頭の低下特性を捉えるため，ま た集水井施工後のバルブの閉止操作や降雨の影響などに よる圧力水頭の変動を調査するために行った。

\section{1 集水井施工前の圧力水頭の変動}

すべり面付近に作用する圧力水頭を正確に求めること は，地すべり抑制工事の施工効果判定や安定解析を行う 際に非常に重要である。流動層別の水位計を用いた王力 水頭の観測結果は，図-10-a に示すように，1983 年 1 月から 10 月まで上部流動層内で観測期間平均 $-1.07 \mathrm{~m}$ (上層孔の深さ $15 \mathrm{~m}$ ), 下部流動層内で同 $-5.89 \mathrm{~m}$ （中 層孔の深さ $25 \mathrm{~m}$ ）亜基岩安定層内で同 $-9.31 \mathrm{~m}$ （下層 孔の深さ $35 \mathrm{~m}$ ) であった。1983 年 8 月下旬の台風によ り秩父気象観測所で連続降雨 $422 \mathrm{~mm}$ が観測され, 三層 孔（上・中・下層孔）の圧力水頭がそれぞれ-0.38 m, $-5.12 \mathrm{~m},-8.90 \mathrm{~m}$ まで上昇した。また，全孔スト レーナー観測孔での地下水位の観測結果は, 各孔とも台 風がもたらした集中豪雨によって最高水位を記録した。 特に上部ブロックは水位の変動幅が大きく台風時には 2 〜10 m の水位上昇がみられた。このことにより，この 斜面の上部ブロックでは, 圧力水頭の上昇が降雨に鋭敏 に反応していることが確認された。

さらにこの斜面の下部ブロックで工事予定の集水井 2 号付近に $15 \mathrm{~m}$ 離れて設置された上層孔（深さ $18 \mathrm{~m}$ ) と下層孔（深さ $27 \mathrm{~m}$ ）の観測結果（図-10-b）による と, 1983 年 10 月から 1984 年 7 月までの観測期間で上層 孔平均水頭 $-11.5 \mathrm{~m}$, 下層孔平均水頭 $-12.9 \mathrm{~m}$ が観測 された。そのうちの上層孔の水頭変動は, 図-10-bに 示すように, 1984 年 3 月から 7 月までの降雨期間に対 し鋭敏に上下することがわかった。

一方，集水井の井筒の掘削が観測孔の圧力水頭に与え
る影響をみると，図-10の説明番号(1)，(2)，(10)，(11)に 示すように, 集水井 1 号の井筒の掘削期間には, 三層孔 とも圧力水頭に与える影響が見られなかった。それは集 水井の余堀り空間にモルタルを注入して集水井周辺の地 下水の侵入及び集水井本体からの漏水を防ぐ効果による ものと考えられる。

\section{2 集水ボーリング孔の掘削による圧力水頭の低下}

図ー10に示すように，集水井 1 号での三段集水ボー リング孔の掘削は，降雨の影響を避けるために 1984 年 の 1 月と 8 月に二つの施工期に分けて行った。最初に集 水井内の下段集水ボーリング孔の施工に着手し，1月か ら 10 本の集水ボーリング工事を行った。下段の集水 ボーリング孔の掘削中に同年の 2 月から中段の集水ボー リング工事も同時に着工した。(3)と(4)の掘削期間をみる と, 三層孔の圧力水頭の低下が明暸に認められる。集水 ボーリング施工に伴う圧力水頭の低下量は，施工前後の 3 力月平均圧力水頭の観測結果の差として, それぞれ 1.6 $\mathrm{m}$ (上層孔), $4.9 \mathrm{~m}$ (中層孔), $17.2 \mathrm{~m}$ (下層孔) であ る。特に下層孔での圧力水頭は大きく低下した。つぎに, 図-10の(5)，(6)と(7)の掘削期間では，それぞれ下段 3 本, 上段 9 本と中段 3 本の集水ボーリングが施工された

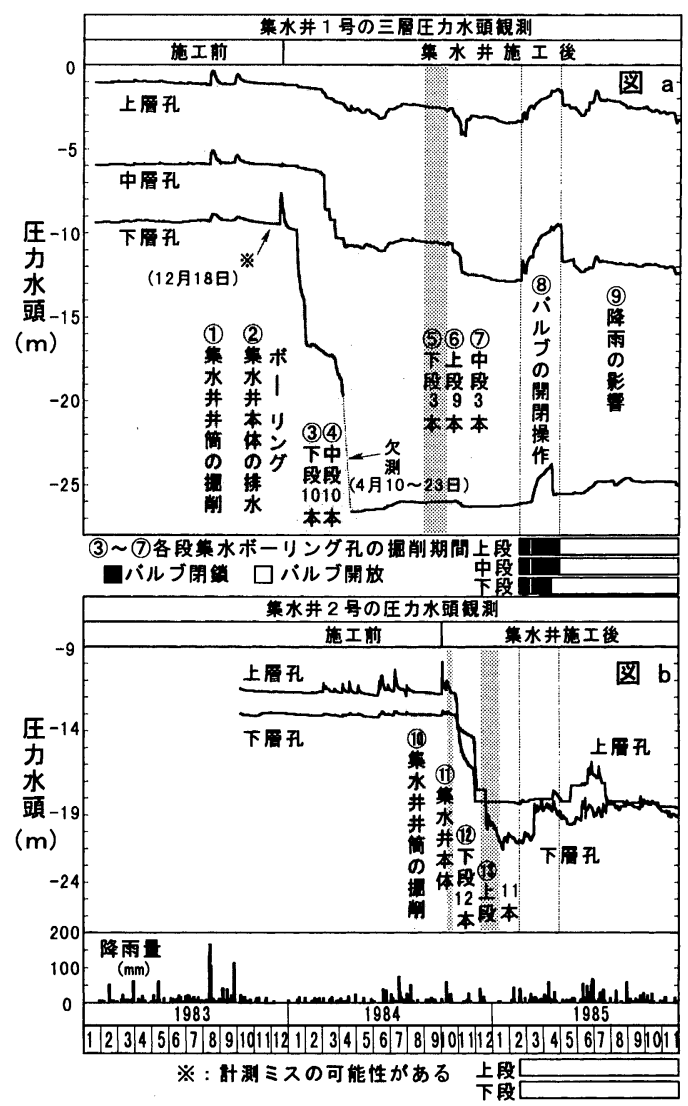

図-10 集水井施工による層別圧力水頭の変動関係 
が，(6の上段 9 本の集水ボーリング孔の施工後のみ三層 孔の圧力水頭の低下が認められた。三層孔の圧力水頭の 低下显はそれぞれ $0.53 \mathrm{~m}, 1.34 \mathrm{~m} ， 0.24 \mathrm{~m}$ が得られた。 特に中莌孔に対応している強風化片岩層で一番大きく約 $1.34 \mathrm{~m}$ の低下显がみられた。一方，集水井 2 号の観測 孔の圧力水頭は，(12)の下段 12 本と(13)の上段 11 本の集水 ボーリング施工により $6.65 \mathrm{~m}$ (上層孔)，8.06 m（下層 孔）の低下がみられた。以上の計測では，いずれも深層 の圧力水頭が浅首のものより低下の割合が大きい。

\section{3 掘削延長・方向による圧力水頭の变動}

図-11 は集水井 1 号下段での各集水ボーリング孔の 掘削方向と水頭の変動関係を図示したものである。集水 ボーリング孔の掘削方向が集水井付近の圧力水頭に与え る影響を検討するため，圧力水頭の時系列変動と施工期 間との関係を(1)から12までの関連图で示している。まず この関連図の関連番号(1)の図を見ると，(1)の上図は集水 井 1 号付近の平面図であり，集水井 1 号に近い観測孔の 水碩値を(1)の下図に示した。下図は水頭値とともに井筒
の掘削工事期間を染色して示している。また，図-12 は集水井 1 号下段及び中段の集水ボーリング孔の掘削に 伴う圧力水頭の低下関係を示す。以下の解析は図-11 と図ー12を対照しながら，掘削延長・方向による压力 水頭の変動を検討する。

まず，図-12の下段の集水ボーリング孔の掘削状況 を検討する。1984 年 1 月 13 日から 4 月 24 日にかけて 10 本の掘削工事が行われた。下段の No. 1 孔の掘削（掘 削方向は図-11の(3に示す) は, 1 月 13 日から始ま り, 16 日に掘削延長 $17 \sim 18 \mathrm{~m}$ 付近での涌水 $4 \ell / \mathrm{min}$ と共にボーリング機のケーシングが締め付けられた。 ケーシングを引き抜き再び最初から掘削し直した。この 時の圧力水頭が急に低下した。そして 17 日に掘削延長 $27.5 \mathrm{~m}$ の硬い石英混り岩石で涌水 $30 \ell / \min$ があり, 圧力水頭が徐々に低下した。No.2 孔の掘削（図-11 の (4)に示す方向）は，21 日に掘削延長 14 17 m 付近にお ける涌水 $3 \ell / \mathrm{min}$ で圧力水頭が徐々に低下していた。 No. 1 孔及びNo. 2 孔のボーリングを実施していない数
(1)

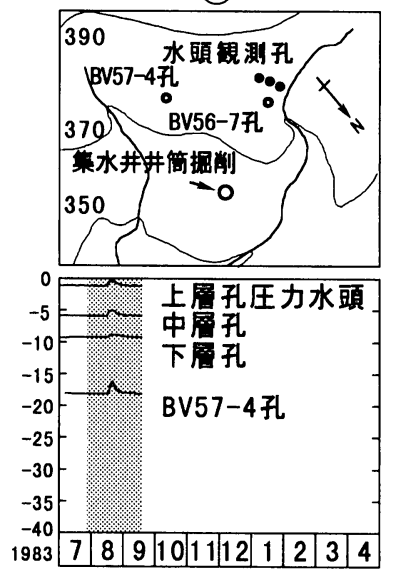

(4)

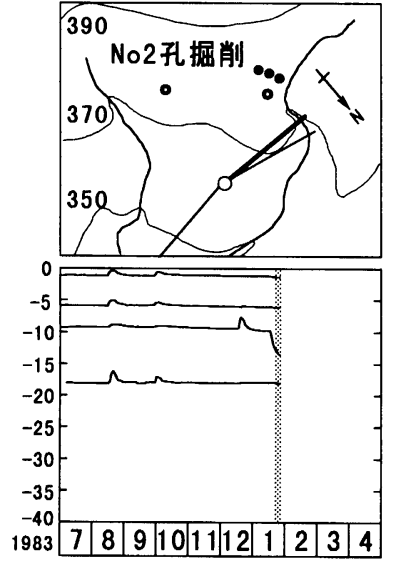

(2)

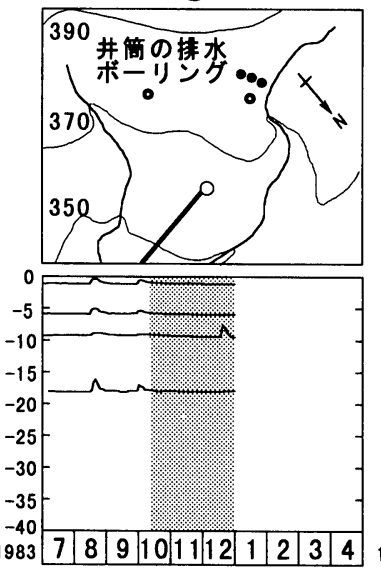

(5)

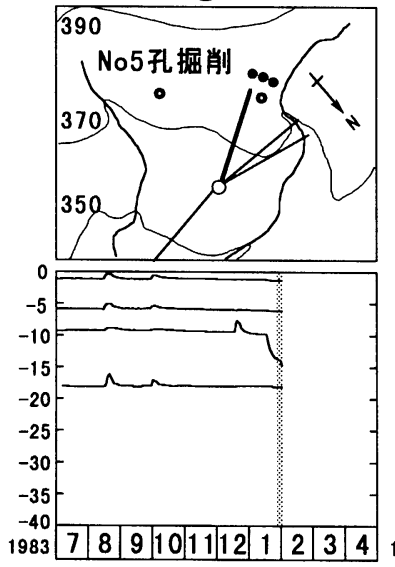

(3)

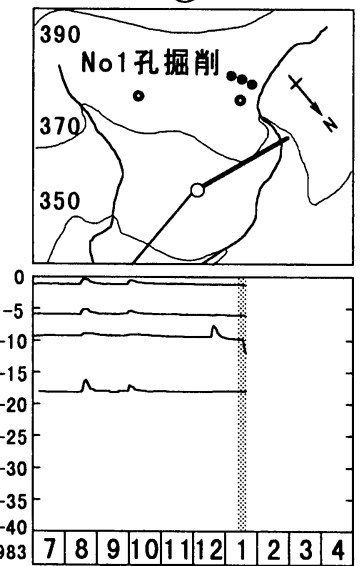

(6)

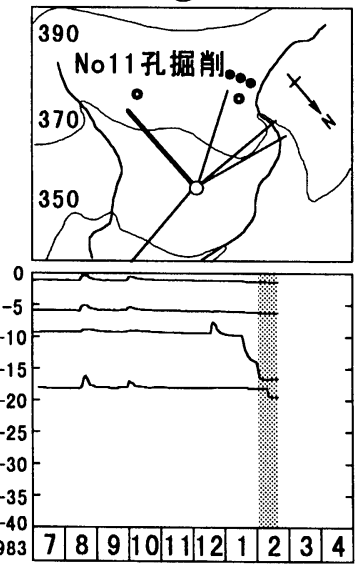

图-11 集水井 1 号の下段集水ボーリング孔の掘削方向と水頭の変化関係（その 1 ） 
日間（25日〜29日の間）にも圧力水頭が低下していた。 No. 5 孔の掘削（図-11の(5)に示す方向）は，掘削方向 が水頭観測孔に向っており，掘削が容易で圧力水頭は急 に $2.81 \mathrm{~m}$ 低下した。この間, 上層孔及び中層孔の水位 は変化しなかった。No.11 孔の掘削（図一11の6に示 す方向）は，全孔ストレーナー観測孔 BV 57-4 に向っ ており, 2 月 9 日から掘削が始まり, 10 日に掘削延長 $32 \mathrm{~m}$ 付近で湧水 $60 \ell / \mathrm{min}$ がありこの時, この BV 57-4 孔は地下水位の低下が見られた。その後, 掘削延長 35 $\mathrm{m}$ 付近でケーシングが切断され, 掘削作業が中止になっ た。13 日に最初から掘削し直し，14 日夜掘削延長 $39 \mathrm{~m}$ まで順調に進んで掘削したが，15日に油圧ポンプ故障 修理のため, 再び掘削作業が中止され，18 日から再開 して掘削延長 $55 \mathrm{~m}$ まで掘削された。次にNo. 11 孔に近 いNo.10 孔，No.9 孔の掘削（図一11の(7)，8に示す方 向）で, BV 57-4 孔の地下水位が急に $17.7 \mathrm{~m}$ 低下した。 No. 4 孔及びNo. 3 孔の掘削は, 掘削方向が変わって圧 力水頭観測孔に向っており, No. 4 孔掘削（図-11の囵
に示す方向）により集水井 1 号下層孔の水頭が多少低下 し, さらにNo. 3 孔の掘削（図-11の12に示す方向）で $7.01 \mathrm{~m}$ 低下した。以上の掘削状況と圧力水頭の低下特 性を見ると, 圧力水頭の低下は集水ボーリングが観測孔 の数 $\mathrm{m}$ 以内に達したときと削孔中に湧水が発生したと きに発生している。集水井 1 号の西側に掘削したNo. 1 孔から No. 5 孔までの 5 本の集水ボーリング孔が三層孔 の水頭の変動に関わっていた。しかし，南側で掘削する と三層孔の圧力水頭はあまり明瞭な変化を示さないこと がわかった。一方, BV 57-4 孔の地下水位の低下は集水 ボーリング孔の No. 9 孔と No. 11 孔の掘削が大きく影響 した。

最後に, 図ー 12 に示す中段の集水ボーリング孔の掘 削に伴う圧力水頭の変化を検討する。1984 年 2 月 8 日 から 5 月 11 日にかけて 10 本の工事が行われたが, その うちの 5 本は掘削孔の時間と番号が確認できないので点 線で示した。最初に掘削した 5 本の状況について説明す る。No. 3 孔の掘削は 2 月 8 日から始まり，11日に掘削
(7)

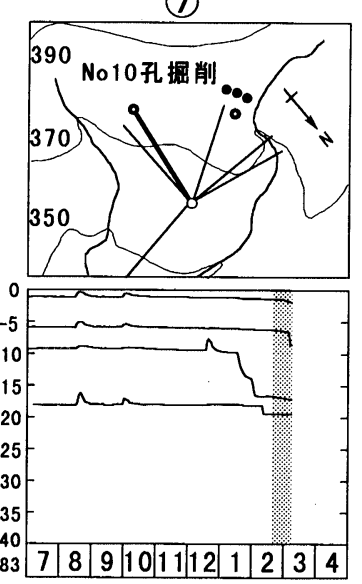

(10)
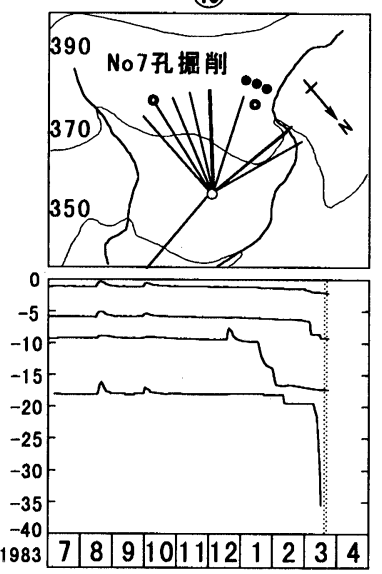

(8)

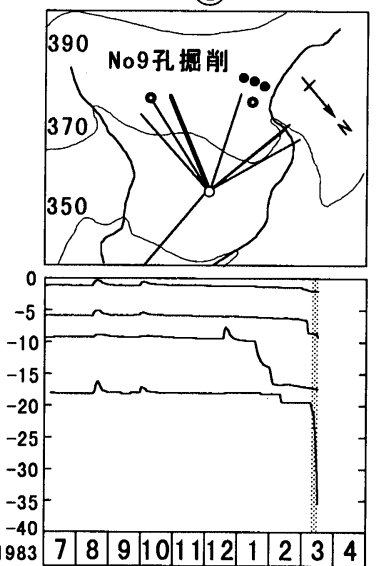

(11)

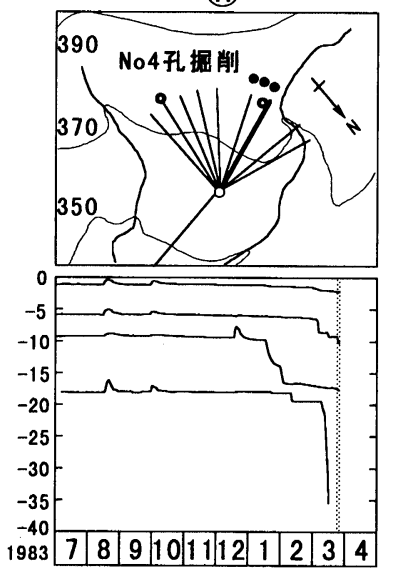

(9)

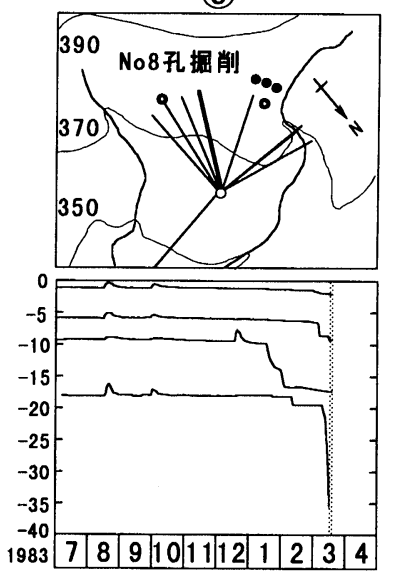

(12)

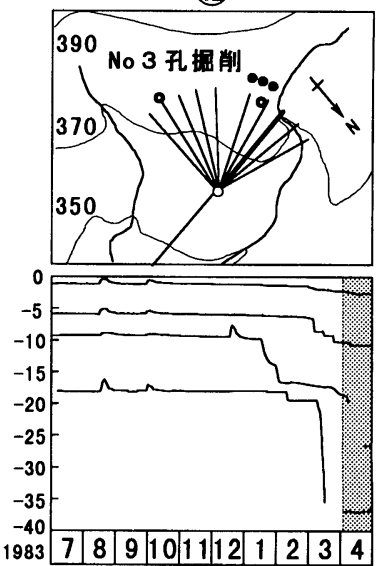

图-11 集水井 1 号の下段集水ボーリング孔の掘削方向と水頭の変化関係（その 2 ） 


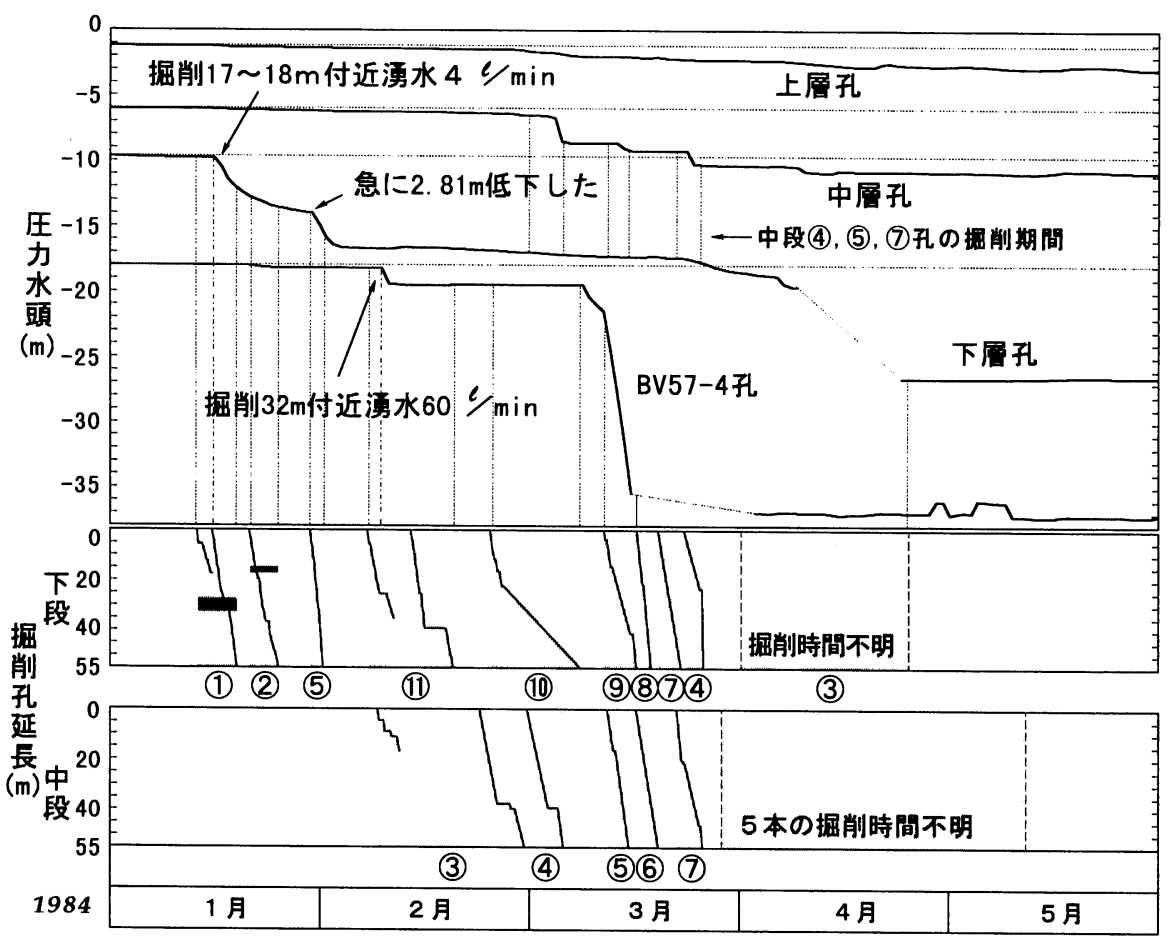

(1) (11)掘削孔の番号黒色片岩口石英混り

图一12 集水井 1 号の集水ボーリング掘削による孔内涌水と圧力水頭の低下関係

延舆 $16.5 \mathrm{~m}$ 付近で涌水 $10 \ell / \mathrm{min}$ と共にヶーシングが 締め付けられ掘削作業がしばらく中止になった。そして 23 日に级初から掘削し直し, 28 日までに掘削延長 $55 \mathrm{~m}$ を掘削した。しかし中層孔の圧力水頭の低下が見られな かった。その後, No. 4 孔から No. 7 孔まで順番に 4 本 を掘削した。その結果, 中層孔での圧力水頭がそれぞれ No. 4 孔で $2.10 \mathrm{~m}$, No. 5 孔で $0.63 \mathrm{~m}$, No. 7 で 1.07 $\mathrm{m}$ 低下した。その期間に, 上層孔での圧力水頭も中段 と下段の集水ボーリング孔の掘削により徐々に低下して いたことが認められた。なお，No.7孔の掘削時には下 段の No. 4 孔も同時に掘削しているので, その影響も考 えられる。

\section{4 全孔ストレーナー観測孔の地下水位変動}

集水ボーリング孔の掘削に伴う全孔ストレーナー観測 孔内の地下水位変動は, 図一13に示すように, BV 57-4 と BV 58-5 のみに $19 \mathrm{~m}, 8.7 \mathrm{~m}$ の水位低下が認められ た。しかし，集水井 1 号での三層孔に近いBV 56-7 孔 の水位は, ほとんど変化がなかった。以上の結果からみ ると, 集水ボーリング孔の集水効果を全孔ストレーナー 観測孔の地下水位から評価することは困難なことが予想 される。その原因として，一般に地すべり地では地すべ り移動によって土塊が摚乱されているため地下水の経路, 流星などの水文条件が複雑であり, しかも, 地すべり地
の地下水の挙動は, 個々の調査地点や深度において異 なった挙動を示すことが多い。

\section{5 バルブの閉止操作による圧力水頭の影響}

斜面内のすべり面付近の圧力水頭の挙動を施工前と類 似した地下水環境を再現するため, バルブの閉止操作実 験を行った。バルブの閉止操作実験は, 井内に設置した 集水ボーリング孔すべての孔ロにバルブを取り付け, バ ルブを閉じることによりその排水機能を一時的に停止さ せ集水井別の圧力水頭観測孔の変動を捉えることが目的 である。

図ー10 に示すように, 集水井 1 号の 3 段バルブは, 1985 年 2 月中旬から 2 週間閉止し, その後三日間だけ 開放した。その後 4 月下旬まで長期に閉止し，4月中旬 以降に下段のみ開放した。また実験期間中は集水井 2 号 のバルブは常時開放された状態であった。その結果とし て, 集水井 1 号の三屡孔の圧力水頭の変動はバルブを閉 止した影響で圧力水頭が鋭敏に上昇していた。バルブを 開放するまでの上昇幅はそれぞれ $1.97 \mathrm{~m}, 3.35 \mathrm{~m}$, $2.38 \mathrm{~m}$ が認められた。なかでも中層孔に対応する強風 化片岩層の圧力水頭の上昇量が敂も大きい。強風化片岩 層は破砕, レキ化が進み, 透水性が高いためと考えられ る。なお, 閉止による下層孔（深度 $35 \mathrm{~m}$ ) の圧力水頭 上昇の応答時間は, 上層孔と中層孔よりやや遅くなるこ 


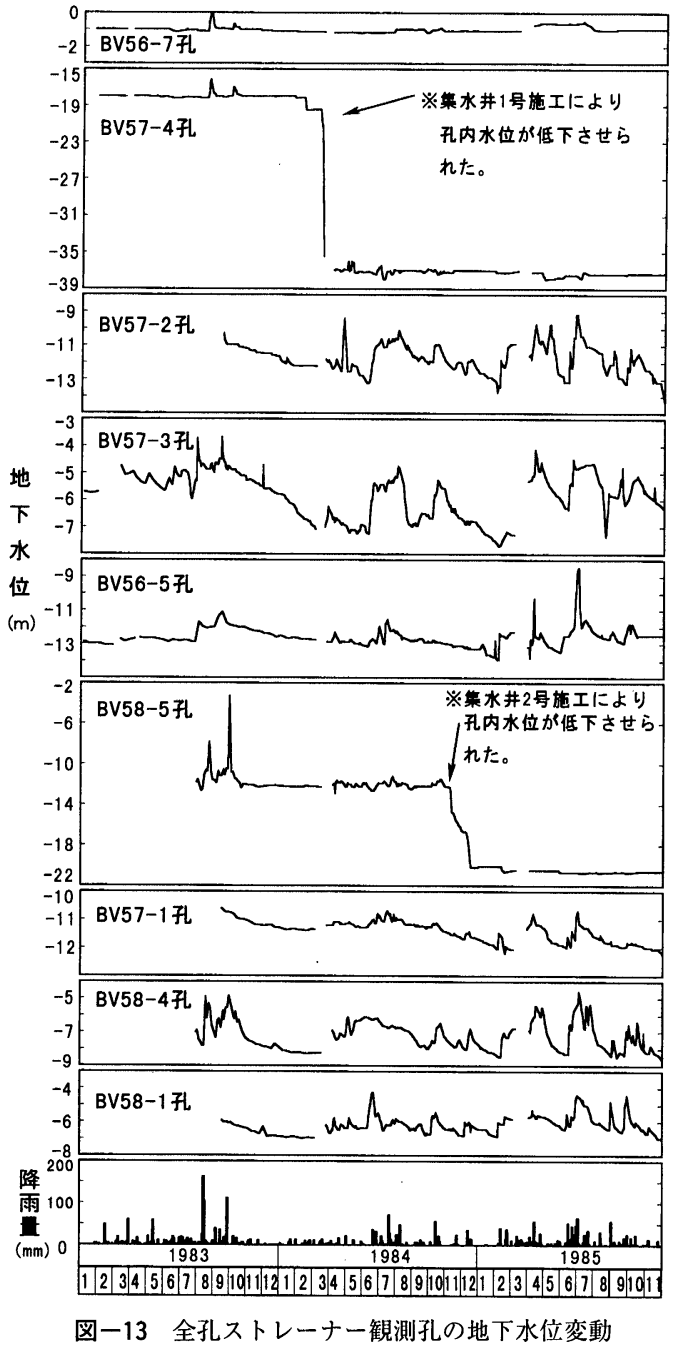

とがわかった。

一方，本実験の期間中，集水井 2 号の下層孔（深度 $27 \mathrm{~m} ）$ の圧力水頭が鋭敏に上昇していることが確認さ れた。集水井 2 号のバルブを閉止しなくても下層孔の圧 力水頭が鋭敏に上昇したことは，バルブ閉止前の一週間 累積降雨量 $33 \mathrm{~mm}$ の降り方にも注目すべきであり, 一 概に集水井 1 号の影響が表われたとは言えないものの何 らかの影響が指摘できよう。

\section{4. あとがき}

平沢地すべり地における集水井施工前後の圧力水頭の 観測結果から集水ボーリング孔の掘削に伴うすべり面付 近の圧力水頭の変動の解析を行い, 集水ボーリング孔の 掘削そのものの効果を明らかにした。施工前の調査では 降雨や圧力水頭などの季節変化データが得られ，その結 果と施工後のデータとを比較して集水井の地下水排除効 果を定量的に明らかにした。さらに，集水ボーリング孔
掘削中のすべり面付近に作用する圧力水頭の低下特性を 捉えるため，掘削中の湧水の現象，また掘削方向と圧力 水頭の変動関係や降雨の影響などの解析を行い，以下の 結果を得た。

1 ）集水ボーリング孔の施工前後における圧力水頭の 低下状況は，集水井 1 号の三層孔及び集水井 2 号の 二層孔の観測結果をみると，深層の圧力水頭が浅層 のものより低下量が大きい。

2 ）集水ボーリング孔の掘削と圧力水頭の低下特性を 見ると, 圧力水頭の低下は集水ボーリングが観測孔 の数 $\mathrm{m}$ 以内に達したときと削孔中に湧水が発生し たときに起っている。圧力水頭の低下効果は観測孔 に近いところまで掘削した集水ボーリング孔が大き く影響した。

3 ）バルブ閉止の操作実験による集水井 1 号の三層孔 の圧力水頭の変動は，バルブ閉止の影響で三層孔の 圧力水頭が鋭敏に上昇し，その中の中層孔に対応す る強風化片岩層の水頭上昇量が最も大きい。

\section{謝辞}

この研究を進める上で森林総合研究所地すべり研究室 から観測デー夕・調査報告書などを提供していただいた。 北海道支所梁瀬秀雄所長にいろいろお世話いただいた。 また, 東京大学の鈴木雅一助教授, 執印康裕助手に多大 な御助言を戴き深く感謝の意を表します。以上の方々に 対し厚く御礼申し上げる。

\section{参考文献}

1）奥園誠之・緒方春樹：地すべり地における地下水排除 工の効果とその調查法, 基礎工, Vol.13, No. 2, pp. 33 $-39,1985$

2 ）丸山清輝・北島義則：地すべり地における集水井の地 下水排除効果に関する検討，地すべり，Vol. 33，No.3， pp. $13-18,1996$

3 ) 岸本良次郎：地下水圧観測施設の一例（地すべり調査 用), 農業土木学会誌, Vol. 36 , No. 10, pp. 23-28, 1969

4）川上 浩：地すべり調査に関連する 2,3 の問題, 地質 学論集, 第 28 号, pp. $87-95,1986$

5 ）松浦純正・梁瀬秀雄：地すべり地における地下水調查 の現状，地すべり研究の発展と未来，大明堂 pp. 229 241,1996

6) 檜垣大助 - 丸山清輝 - 吉田克美・吉松弘行：地すべり 地における間隙水圧変動の観測，地すべり，Vol.28， No. 3, pp. 9-16，1991

7 ) 吉田昭治·稲葉一成·中野俊郎 - 竹内伸一・佐藤 修：地すべり斜面の自由地下水, 地下水圧の観測と解 析について, 土と基礎第 39 巻 12 号, pp. 29-34, 1991

8 ）林野庁森林総合研究所：地すべり対策調查報告書（埼 玉県児玉郡坚玉町平沢地区）1981～1985

9 ) 埼玉県農林部林務課：平沢地区地すべり調査（観測） ＜埼玉県児玉郡児玉町大字太駄地内＞報告書，1982 1984

10）埼玉県農林部林務課：平沢地すべり対策工事における 地質掘削工程表, 1984 
集水ボーリングエの効果に関する定量的評価手法の提案

「地すべり」Vol. 35, No. 3 (通巻第 135 号) pp. 1 7, 1998 年（平成 10 年）12月

樢飼恵三, 蔡 飛, 若井明彦, 阪上最一

3 次元飽和一不飽和浸透流解析法とせん断強度低隇 FEM を用いて, 集水横ボーリング工の効果を定量的に評

価した。ボーリングエの設置間隔，長さ，方向などが斜面の安全率上昇に及ほすす影響が明らかにされた。

\section{掘削粘性土斜面の安定解析に関する一考察}

「地すべり」Vol. 35, No.3 (通巻第 135 号) pp. 8 14, 1998 年（平成 10 年）12 月

馮 鉄群, 山上拓男

粘性土地盤中の掘削斜面が時の経過と共に安定性を減じる現象を定量的に表現する上で，一般に行われている ような飽和連成弹塑性有限要素解析は正しい結果を与えない。すなわち, 掘削除荷に伴って地盤が膨張するとき, 地表面から空気を吸い込み，局所的に不飽和域が出現することを認めた解法をとらなければならない。

\section{蛇紋岩地すべりに対する鉱物学的一考察}

「地すべり」Vol. 35, No. 3 (通巻第 135 号) pp. 15 23, 1998 年（平成 10 年）12 月 横田公忠, 矢田部龍一, 八木則男

蛇紋岩地帯では地質境界部で多くの地すべりが発生している。本論文では, この理由を蛇紋岩の生成過程にま で遡って鉱物学的に検討している。具体的には, 顕微鏡観察, X 線回析, 蛍光 X 楾分析により蛇紋岩の釷物学 的特性を調べ, また, 文献調查に基づく検討を行っている。それらの結果, 蛇紋岩の特性は蛇紋岩と磁鉄鉱それ とブルサイトが共存しているところにあり, 風化に弱く細粒化しやすいが, すべり面と成り得る小さなせん断抵 抗角を持つ粘土鉙物は生成されない。蛇紋岩体に隣り合って, 緑泥石層などが形成されやすく, これらはすべり 面と成り得る粘土釷物を生成しやすい。したがって, 蛇紋岩体との境界部で多くの地すべりが発生しやすいと結 論できる。

\section{集水井集水工法によるすべり面付近の間隙水圧の変動特性}

一埼玉県児玉郡児玉町平沢地すべり地を例としてー

「地すべり」Vol. 35, No. 3 (通巻第 135 号) pp. 24 33，1998 年（平成 10 年）12 月

曹 崇銘, 太田猛彦, 竹内美次, 松浦純生, 落合博貴

本研究では.すべり面付近の間隙水圧の変動特性を把握するためすべり面付近に部分ストレーナー区間を設け, 層別水位計を用いた圧力水頭（間隙水圧）の測定と，それに対応する深度に集水井から部分ストレーナーによる 集水ボーリングを施工し, 集水ボーリング施工前後の圧力水頭の変動を観測した。これらの結果を基に, 集水ボー リングの施工が圧力水頭の変動特性に与える影響を明らかにし, さらに圧力水頭の時系列変動と集水ボーリング 孔の掘削延長・方向との関係を検討して集水井の施工効果の評価を試みた。

\section{アンカーを用いた梁のたわみ・応力解析}

「地すべり」Vol. 35, No. 3 (通巻第 135 号) pp. 34 38, 1998 年（平成 10 年）12 月 柏原公二郎, 原 裕, 河内俊雄

岩盤切り取り面上の法枠にアンカーカを加えた場合の, 梁の変形と応力を求める式を, 二つのモデルについて 導くことが出来た。

モデル 2 に対しChang の計算法を用いると, 曲げモーメントはアンカー点でー4. $5 \%$, 有効長は+50\% の誤 差が生じ設計上不利な状態が発生する。 